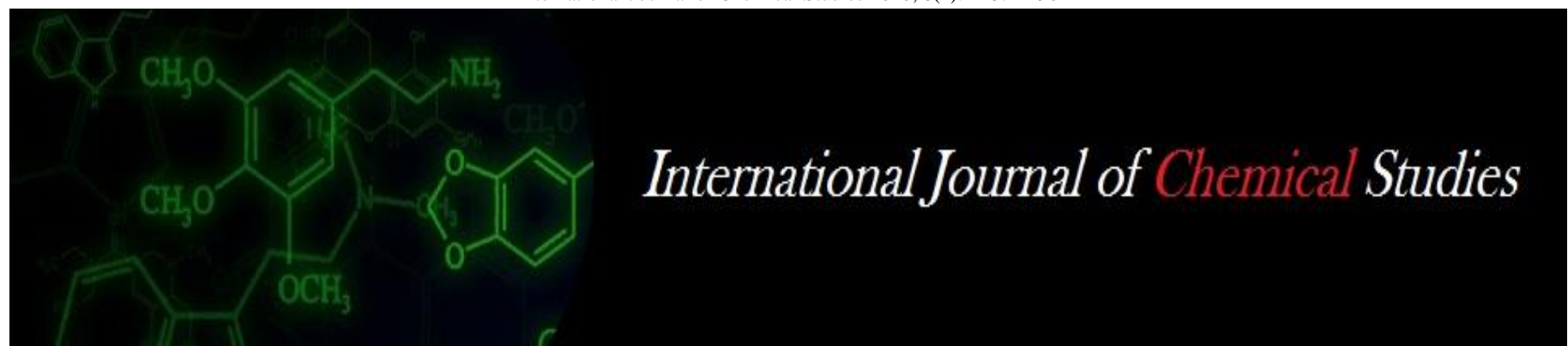

P-ISSN: 2349-8528

E-ISSN: 2321-4902

www.chemijournal.com

IJCS 2020; 8(2): 2187-2190

(C) 2020 IJCS

Received: 13-01-2020

Accepted: 15-02-2020

Jitendra Kumar

ICAR-IISS, Navibagh, Berasia

Road, Bhopal, Madhya Pradesh, India

H Kalita

ICAR RC for NEH Region AP Centre Basar. Arunachal,

Pradesh, India

Rajesh A Alone

ICAR RC for NEH Region AP,

Centre Basar, Arunachal

Pradesh, India
Corresponding Author:

Jitendra Kumar

ICAR-IISS, Navibagh, Berasia

Road, Bhopal, Madhya Pradesh,

India

\section{Effect of organic, inorganic manure and lime application on soil physiochemical properties and yield of maize in acidic soil of mid hill of Arunachal Pradesh}

\author{
Jitendra Kumar, H Kalita and Rajesh A Alone
}

DOI: https://doi.org/10.22271/chemi.2020.v8.i2ag.9075

\begin{abstract}
This study was aimed to determine the effects of organic and inorganic manures and lime application on growth and yield of maize and their impacts on soil physico-chemical characteristics. Vermicompost, and biofertilizers were applied as organic nutrient source while urea, diammonium phosphate (DAP) and Murate of potash (MOP) were used at different concentrations as inorganic nutrients source viz., T1: Unfertilized control; T2: Vermicompost $\left(7\right.$ tha $\left.^{-1}\right)$ T3 Lime applaction 3 tha $^{-1}$ year $^{-1}$ T4 50\% RDF with lime application T5 50\% RDF T6 100\% RDF T7 Biofertilizers. Results showed that growth and yield of maize were substantially improved by fertilizer application alongside organic manures whereas soil total organic $\mathrm{C}$ and available $\mathrm{N}, \mathrm{P}, \mathrm{K}$ contents increased when inorganic fertilizers were applied alone or in combined with organic manures. However, soil $\mathrm{pH}$ and soil bulk density decreased due to application of vermicompost. The highest plant height, were obtained in application $100 \% \mathrm{RDF}$ at Vegetative stage while at the time of harvesting highest plant height was obtained in 50\% RDF with lime application The highest yield was obtained in 100\% RDF followed by the application of 50\% RDF with lime application. Conclusively, integration of inorganic fertilizers with organic manures can be used with optimum rates to improve crop productivity on sustainable basis.
\end{abstract}

Keywords: Lime application, acidic soil yield of maize \& mid hill of Arunachal Pradesh

\section{Introduction}

Maize (Zea mays L.) is one of the most versatile emerging crops having wider adaptability under varied agro-climatic conditions. Globally, maize is known as queen of cereals. It is cultivated nearly $150 \mathrm{~m}$ ha in about 160 countries having wider diversity of soil, climate, biodiversity and management practices that contributes $36 \%(782 \mathrm{mt})$ in the global grain production. The United States of America (USA) is the largest producer of maize contributes nearly $35 \%$ of the total production in the world and maize is the driver of the US economy. The USA has the highest productivity $\left(>9.6 \mathrm{t} \mathrm{ha}^{-1}\right)$ which is double than the global average (4.92 tha $^{-1}$ ). Whereas, the average productivity in India is 2.43 tha $^{-1}$ (https://farmer.gov.in)

In India, maize is the third most important food crops after rice and wheat. In addition to staple food for human being and quality feed for animals, Maize serves as a basic raw material as an ingredient to thousands of industrial products that includes starch, oil, protein, alcoholic beverages, food sweeteners, pharmaceutical, cosmetic, film, textile, gum, package and paper industries etc.

The maize is cultivated throughout the year in all states of the country for various purposes including grain, fodder, green cobs, sweet corn, baby corn, popcorn. The predominant maize growing states that contributes more than $80 \%$ of the total Maize production are Andhra Pradesh (20.9\%), Karnataka (16.5\%), Rajasthan (9.9\%), Maharashtra (9.1\%), Bihar (8.9\%), Uttar Pradesh (6.1\%), Madhya Pradesh (5.7\%), Himachal Pradesh (4.4\%) (https://farmer.gov.in). Apart from these states' maize is also grown in Jammu and Kashmir and North-Eastern states. Hence, the Maize can be grown successfully in variety of soils ranging from loamy sand to clay loam. However, soils with good organic matter content having high water holding capacity with neutral $\mathrm{pH}$ are considered good for higher productivity. Being a sensitive crop to moisture stress particularly excess soil moisture and 
salinity stresses; it is desirable to avoid low lying fields having poor drainage and also the field having higher salinity. Therefore, the fields having provision of proper drainage should be selected for cultivation of Maize.

In North east part of India due to high rainfall there soil becomes highly acidic in nature, even less than $4.5 \mathrm{pH}$ also been reported. Hilly terrain and low $\mathrm{pH}$ is two most important constraint of north east to for achieving the optimum and sustainable crop yield. With the majority of agricultural soils nationally at low soil $\mathrm{pH}$ status, the under application of lime and organic manure and bioferilizers is likely costing farmers dearly in terms of crop yield at same time the improve the soil quality. Lime is a soil conditioner and corrects soil acidity by neutralizing the acids present and allowing the microorganisms and earthworms to thrive and break down plant residues, animal manures and organic matter. This helps to release stored soil nutrients such as nitrogen (N), phosphorus (P), potassium (K), sulphur (S) and micronutrients for plant uptake.

\section{Material and methods}

The study was conducted in West Siang district of Arunachal Pradesh (Fig.1) longitude $93.57^{\circ} \mathrm{E}$ to $95.23^{\circ} \mathrm{E} \&$ Latitude $27.69^{0} \mathrm{~N}$ to $29.20^{\circ} \mathrm{N}$.) At an altitude of approximately $680 \mathrm{~m}$. The mean annual precipitation approximately $2100 \mathrm{~mm}$, with nearly $79 \%$ falling between May and September; the mean annual temperature is $20.2^{\circ} \mathrm{C}$, with a maximum monthly mean value of $26.2^{\circ} \mathrm{C}$ (August) and a minimum monthly mean value of $11.9^{\circ} \mathrm{C}$ (January).

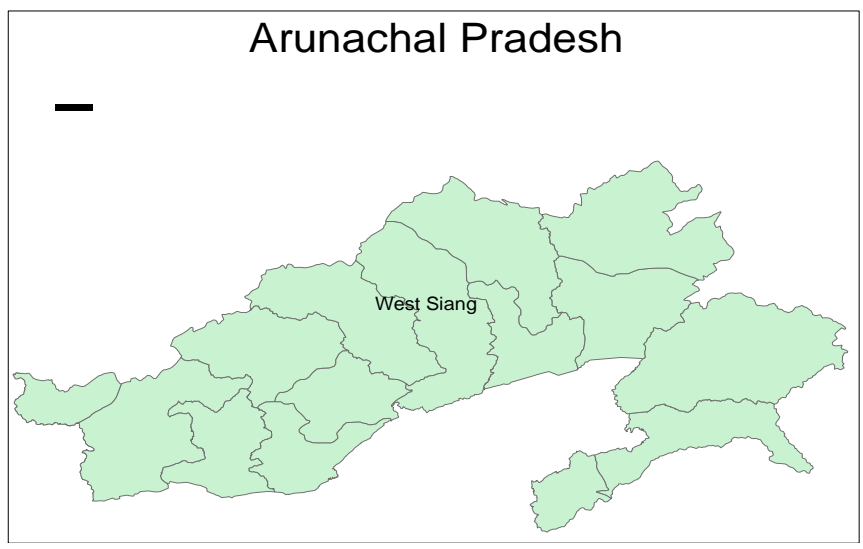

Fig 1: Study Area

The field was laid out in randomize complete block design (RCBD) which is replicated three (3) times on a gross plot size of $5.0 \mathrm{~m} \times 4 \mathrm{~m}$. The organic nutrient sources used were vermicompost and biofertilizer whereas the inorganic sources are Urea, Di-ammonium phosphate (DAP) and Muriate of potash (MOP). Seven treatments involving a combination of various nutrients from different sources (organic and inorganic) were used which include T1: Unfertilized control; T2: Vermicompost ( $\left.7 \mathrm{t} \mathrm{ha}^{-1}\right) \mathrm{T} 3$ Lime applaction $3 \mathrm{t} \mathrm{ha}^{-1} \mathrm{year}^{-1}$ T4 50\% RDF with lime application T5 50\% RDF T6 100\% RDF T7 Biofertilizers). Maize Variety RCM 61 was used as experimental material for sowing purpose at a depth of 3-5 cm using a spacing of $60 \mathrm{~cm} \times 15 \mathrm{~cm}$ using $30 \mathrm{~kg} \mathrm{ha}^{-1}$ recommended dose of sowing seed.

The recommended dose of organic fertilizer (Vermicompost $\&$ FYM) used was 7 tha $^{-1}$ and this were uniformly incorporated into the soil one month before sowing as per treatments in each plot. Furthermore, the recommended dose of inorganic fertilizer (RDF) used was 120:60:40 NPK kg ha${ }^{1}$, whereas half $(1 / 2)$ of urea along with complete DAP and MOP were applied at sowing time as basal doses and the remaining urea was applied as top dressed at 36 and 70 days after sowing (DAS) respectively as a split doses. Plant height $(\mathrm{cm})$ and leaf area (LA) were measured and recorded, whereas at maturity period the yield plant $(\mathrm{g})$ was measured and recorded. However, after crop harvesting the soil sample from trial field was analyzed for determination of soil physicchemical properties (organic carbon and NPK) and the measured data were subjected to Analysis of variance (ANOVA) and their means was separated using Duncan multiple Range Test (DMRT) at 5\% level of significance.

\section{Result and discussion}

Effect of organic and inorganic sources of nutrients on soil physical

\section{Properties}

\section{Soil physical properties}

Soil bulk density (BD)values in different treatments ranged from (Table 1) 0.97 to $112 \mathrm{Mg} \mathrm{m}^{-3}$. Bulk density of soil was significantly influenced by the application of organic and inorganic fertilizer. The lowest BD was recorded in the T2 which comprising $100 \%$ nutrient supplied through application of vermicompost with the rate of $7 \mathrm{tha}^{-1}$ whereas the highest $\mathrm{BD}$ was recorded in the control treatment. This treatment also showed significantly higher water holding capacity (WHC) whereas the lowest WHC was recorded in the control. Control is at par with the $50 \%$ RDF application further the control is at par with the $\mathrm{T} 4$ and $\mathrm{T} 5$ which comprising application of $50 \%$ RDF with lime application and 50\% RDF respectively. Similar result was recorded in the available water capacity. Available water content highest was recorded in the T6 comprising $100 \%$ RDF application of inorganic fertilizers. Sharma and Gupta (1998) ${ }^{[8]}$ noticed decrease in soil bulk density to $1.23 \mathrm{Mg} \mathrm{m}^{-3}$ with application of 50 per cent $\mathrm{N}, \mathrm{P}_{2} \mathrm{O}_{5}$ and $\mathrm{K}_{2} \mathrm{O}+50$ per cent $\mathrm{N}$ through FYM after the harvest of maize crop under agro-climatic conditions of Rajouri. Sujata et al. (2008) ${ }^{[9]}$ reported lower soil bulk density (1.19 and 1.26 $\mathrm{Mg} \mathrm{m}^{-3}$, at 0-15 and $15-30 \mathrm{~cm}$ soil depth, respectively) with the application of organic manure at $1 \mathrm{t} \mathrm{ha}^{-1}$. The treatment with vermicompost at 3.67 tha $^{-1}$ recorded also similar soil bulk density values at $0-15$ and $15-30 \mathrm{~cm}$ soil depth. Reduction in bulk density of soil was also reported by Choudhary and Kumar (2013) ${ }^{[4]}$ with the application of FYM $10 \mathrm{t} \mathrm{ha}^{-1}$ and cow dung manure at $10 \mathrm{t} \mathrm{ha}^{-1}$. Bhriguvanshi (1988) ${ }^{[3]}$ was also reported the application of FYM resulted in improvement of water holding capacity compare to other inorganic application treatment sandy loam (54.2\%) and clay loam $(57.8 \%)$ soil.

Table 1: Effect of organic and inorganic nutrient on soil physical parameters.

\begin{tabular}{|c|c|c|c|c|}
\hline Treatments & Bulk Density (Mg/m3) & Porosity (\%) & WHC (\%) & AWC (\%) \\
\hline Unfertilized control & 1.12 & 53.65 & 53 & 31 \\
\hline Vermicompost (7 t/ha) & 0.97 & 63.16 & 63 & 41 \\
\hline Lime applaction 3 Tonn/ha /year & 1.15 & 56.58 & 56 & 33 \\
\hline 50\% RDF with lime application & 1.09 & 55.07 & 55 & 39 \\
\hline
\end{tabular}




\begin{tabular}{|c|c|c|c|}
\hline 50\% RDF & 1.11 & 54.35 & 54 \\
\hline $100 \%$ RDF & 1.01 & 61.70 & 61 \\
\hline Biofertilizers & 1.09 & 54.87 & 54 \\
\hline SEm & 0.001 & 0.56 & 0.55 \\
\hline LSD & 0.15 & 3.45 & 3.45 \\
\hline
\end{tabular}

\section{Soil chemical properties}

The effect of treatment was significantly influenced the $\mathrm{pH}$ (Table 2) of the soil the treatment $\mathrm{T} 3$ and $\mathrm{T} 4$ comprising application of lime along with $50 \%$ nutrient from vermicompost and inorganic fertilizers respectively showed significant improvement in soil ph in comparison to the other treatment and the highest ph was recorded in lime application along with $50 \%$ RDF and lowest was recorded in the control. The application of lime in the treatment showed higher $\mathrm{pH}$ compare to the treatment with no lime application.

Soil Organic Carbon (SOC) The application of organic and inorganic manure significantly influence the soil organic carbon status of soil the soil the highest SOC was recorded in the treatment comprise application of $100 \%$ nutrient through vermicompost followed by the treatment with $100 \% \mathrm{RDF}$ through inorganic fertilizers (Table. 2) lowest SOC was recorded in treatment with biofertilizer application which was at par with the control.

\section{Effect of organic and inorganic fertilizers on available nutrient content of soil \\ Major nutrients}

The available nitrogen status of soil was significantly influenced by various treatments. It ranged from 225.6 to $297.78 \mathrm{~kg} \mathrm{ha}^{-1}$. The highest available nitrogen content of soil was recorded in the treatment receiving $100 \%$ nutrient through inorganic fertilizers, and lowest was recorded on the control. There was no direct evidence reflected to that lime application influenced the availability of Nitrogen. Where as in the availability of Phosphorous (Table 2) the treatment comprising the lime application showing improved availability of $\mathrm{P}$ compare to the other treatment without lime application. The application of lime resulting in increased solubility to the readily soluble $\mathrm{P}$ in the soil solution the increase the availability of $\mathrm{P}$. the application of organic amendment also increase the available $\mathrm{P}$ this observation is with the consistant with Lee et al. 2004. The available potash was significantly influenced by the application of nutrient and $100 \%$ RDF was found the highest followed by 50\% RDF with lime application. And remaining all the treatment is at par to each other hence there was direct evidence of application of lime application on the availability of $\mathrm{K}$ was found. Kumar et al. $2007^{[6]}$ was also reported that Significantly higher uptake of nitrogen, phosphorus and potassium by maize crop were noticed under treatment receiving vermicompost @ $2.5 \mathrm{t}$ ha-1 over on a clay loam soil under agro-climatic conditions of Raichur. In a field experiment conducted by Sujata et al. (2008) ${ }^{[9]}$ at Dharwad on a black clayey soil with initial available $\mathrm{N}, \mathrm{P}$ and $\mathrm{K}$ content, application of poultry manure at 1 tha $^{-1}$ resulted in higher uptake of $\mathrm{N}, \mathrm{P}$ and by maize crop followed by application of vermicompost at 3.67 tha $^{-1}$

Table 1: Effect of organic and inorganic nutrient on soil chemical parameters.

\begin{tabular}{|c|c|c|c|c|c|}
\hline Treatments & pH & SOC $\left(\mathbf{g k g}^{-1}\right)$ & Avail N (Kgha $\left.^{-1}\right)$ & Avail P2o5 (Kgha $\left.^{-1}\right)$ & Avail K (Kgha $\left.^{-1}\right)$ \\
\hline Unfertilized control & 5.12 & 9.01 & 225.61 & 10.61 & 335.61 \\
\hline Vermicompost (7 t/ha) & 5.16 & 10.28 & 278.25 & 13.25 & 338.25 \\
\hline Lime applaction 3 Tonn/ha /year & 6.33 & 9.33 & 265.08 & 20.08 & 349.58 \\
\hline 50\% RDF with lime application & 6.59 & 9.29 & 266.59 & 21.59 & 361.59 \\
\hline 50\% RDF & 5.19 & 9.06 & 263.06 & 18.06 & 344.56 \\
\hline 100\% RDF & 5.28 & 10.12 & 297.78 & 15.28 & 369.78 \\
\hline Biofertilizers & 5.33 & 8.83 & 267.33 & 18.33 & 337.33 \\
\hline SEm & 0.019 & 0.58 & 42.9 & 0.78 & 51.23 \\
\hline LSD & 0.542 & 0.95 & 25.94 & 3.5 & 28.37 \\
\hline
\end{tabular}

\section{Effect of organic and inorganic fertilizers on plant growth parameters.}

The plant height, leaf area index and dry matter were recorded at two stage grand and harvest stage. Chlorophyll content was recorded periodically and average was done. The effect of nutrient application along with lime was significantly influenced the plant growth parameters (Table 3). The RDF $100 \%$ application showed the highest growth in the plant height at grand stage where as at harvesting stage highest plant height was recorded in 50\% RDF with lime application this is might be the increase in $\mathrm{pH}$ influenced the availability of $\mathrm{P}$ and other nutrient similar result was recorded in the leaf area index. Moreover the lime application improve the yield attributes compare to the $7 \mathrm{t} /$ ha vermicompost application. The chrophyll content was also showed similar result. The grain weight was also showing the similar trend and highest yield was recorded in the $100 \%$ RDF application and was lowest was in the unfertilized block this is in consistant with Barod et al. $2012^{[2]}$. Kler and Walia (2006) ${ }^{[5]}$ reported significantly higher dry matter accumulation (132.6 q/ha) by maize crop at harvesting stage with application of FYM at and recommended chemical fertiliser alone under agro-climatic conditions of Ludhiana. At Jhalawar, application of RDF + FYM at $10 \mathrm{t} / \mathrm{ha}$ resulted in higher grain yield $(3.12 \mathrm{t} / \mathrm{ha})$ in maize. The lowest grain yield of 1.19 was registered under control plot without FYM (Tetarwal et al., 2011) ${ }^{[10]}$.

Table 3: Effect of organic and inorganic fertilizers on plant growth parameters

\begin{tabular}{|c|c|c|c|c|c|c|c|c|}
\hline Treatments & \multicolumn{2}{|c|}{ Plant Height (cm) } & Chlorophyll Content & \multicolumn{2}{|c|}{ Leaf Area Index } & \multicolumn{2}{|c|}{ Dry Matter (g) } & Grain Weight (gplant $\left.{ }^{-1}\right)$ \\
\hline & Grand & Harvest & Grand & Grand & Harvest & Grand & Harvest & \\
\hline Unfertilized control & 71.26 & 166.259 & 49 & 2.38 & 1.38 & 66.38 & 261.38 & 106.38 \\
\hline Vermicompost (7 t/ha) & 74.66 & 179.655 & 51 & 2.81 & 1.60 & 69.60 & 264.60 & 114.60 \\
\hline Lime applaction 3 Tonn/ha /year & 72.07 & 185.569 & 55 & 3.17 & 2.48 & 72.98 & 282.98 & 137.98 \\
\hline
\end{tabular}




\begin{tabular}{|c|c|c|c|c|c|c|c|c|}
\hline 50\% RDF with lime application & 76.38 & 203.879 & 55 & 3.59 & 2.59 & 74.59 & 296.09 & 151.09 \\
\hline 50\% RDF & 82.07 & 193.793 & 49 & 3.49 & 2.03 & 74.93 & 275.99 & 148.99 \\
\hline 100\% RDF & 83.79 & 200.069 & 56 & 3.53 & 2.49 & 75.99 & 284.03 & 156.53 \\
\hline Biofertilizers & 76.24 & 181.241 & 50 & 2.24 & 1.24 & 69.24 & 270.24 & 126.24 \\
\hline SEm & 0.42 & 27 & 2.3 & 0.07 & 0.09 & 1.73 & 33.79 & 29.88 \\
\hline LSD & 5.9 & 5.8 & NS & 1.02 & 1.23 & 5.2 & 23.04 & 21.67 \\
\hline
\end{tabular}

\section{Conclusion}

Application of lime can increase the $\mathrm{pH}$ of the soil, increase the availability of Phosphorous influence of the different source of nutrient on the plant growth parameters inorganic fertilizer application has influencing the growth parameters as well the availability of soil nutrient immediately whereas the organic source of nutrient affect soil nutrient and plant growth parameters comparatively with lower rate. The effect of lime application showed positive impact on growth attributes of crop, eventhouh it was not evident in the influencing the soil chemical parameters directly except $\mathrm{pH}$ and Phosphorpus availability. The observed positive effect of lime on maize growth was therefore likely due to its effect in increasing the $\mathrm{pH}$ and therefore increasing availability of most nutrients to maize.

\section{Acknowledgment}

The authors are highly thankful to the director ICAR RC for NEH Region, Umroi Road Umiam. For providing the financial assistance to carry out trial under the NICRA Project.

\section{Reference}

1. https://farmer.gov.in

2. Barod NK, Dhar S, Kumar A. Effect of nutrient sources and weed control methods on yield and economics of baby corn (Zea mays). Indian Journal of Agronomy. 2012; 57(1):96-99.

3. Bhriguvanshi SR. Long-term effect of high doses of farmyard manure on soil properties and crop yield. J. Indian Soc. Soil Sci. 1988; 36:784-786.

4. Choudhary VK, Suresh KP. Maize production, economics and soil productivity under different organic source of nutrients in eastern himalayan region, India, 2013.

5. Kler DS, Walia SS. Organic, integrated and chemical farming in wheat (Triticum aestivum) under maize (Zea mays)-wheat cropping system. Indian Journal of Agronomy. 2006; 51(1):6-9.

6. Kumar P, Halepyati AS, Pujari BT, Desai BK. Effect of integrated nutrient management on productivity, nutrient uptake and economics of maize (Zea mays L.) under rainfed condition. Karnataka Journal of Agricultural Sciences. 2007; 20(3):462-465.

7. Lee CH, Park CY, Do Park K, Jeon WT, Kim PJ. Longterm effects of fertilization on the forms and availability of soil phosphorus in rice paddy. Chemosphere. 2004; 56(3):299-304.

8. Sharma MP, Gupta JP. Effect of Organic Materials on Grain Yield and Soil Properties in Maize (Zea mays): Wheat (Triticum aestivum) Cropping System. Indian journal of agricultural Science. 1998; 68(11):715-717.

9. Sujatha MG, Lingaraju BS, Palled YB, Ashalatha KV. Importance of integrated nutrient management practices in maize under rainfed condition. Karnataka Journal of Agricultural Sciences. 2008; 21(3):334-338.

10. Tetarwal JP, Ram B, Meena DS. Effect of integrated nutrient management on productivity, profitability, nutrient uptake and soil fertility in rainfed maize (Zea mays). Indian Journal of Agronomy. 2011;56(4):373376. 